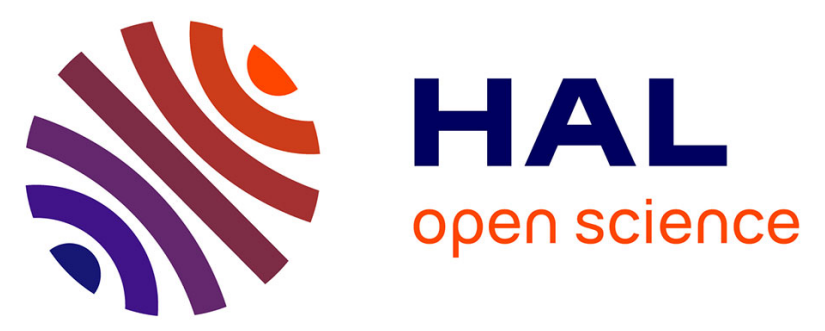

\title{
The influence of phenolic hydroxy substitution on the electron transfer and anti-cancer properties of compounds based on the 2-ferrocenyl-1-phenyl-but-1-ene motif
}

Elisabeth A. Hillard, Pascal Pigeon, Anne Vessières, Christian Amatore, Gérard Jaouen

\section{To cite this version:}

Elisabeth A. Hillard, Pascal Pigeon, Anne Vessières, Christian Amatore, Gérard Jaouen. The influence of phenolic hydroxy substitution on the electron transfer and anti-cancer properties of compounds based on the 2-ferrocenyl-1-phenyl-but-1-ene motif. Dalton Transactions, 2007, 43, pp.5073-5081. 10.1039/b705030e . hal-01230399

\section{HAL Id: hal-01230399 \\ https://hal.science/hal-01230399}

Submitted on 22 Nov 2018

HAL is a multi-disciplinary open access archive for the deposit and dissemination of scientific research documents, whether they are published or not. The documents may come from teaching and research institutions in France or abroad, or from public or private research centers.
L'archive ouverte pluridisciplinaire HAL, est destinée au dépôt et à la diffusion de documents scientifiques de niveau recherche, publiés ou non, émanant des établissements d'enseignement et de recherche français ou étrangers, des laboratoires publics ou privés. 


\title{
The influence of phenolic hydroxy substitution on the electron transfer and anti-cancer properties of compounds based on the 2- ferrocenyl-1-phenyl-but-1-ene motif
}

\author{
Elizabeth Anne Hillard, ${ }^{a}$ Pascal Pigeon, ${ }^{a}$ Anne Vessières, ${ }^{a}$ Christian Amatore ${ }^{b}$ and \\ Gérard Jaouen $^{* a}$
}

\begin{abstract}
${ }^{a}$ Laboratoire de Chimie et Biochimie des Complexes Moléculaires, UMR CNRS 7576, Ecole Nationale Supérieure de Chimie de Paris, 11 rue Pierre et Marie Curie, 75231, Paris, Cedex 05, France. E-mail: gerard-jaouen@enscp.fr; Fax: +33 1432600 61; Tel: +331 43269555 ${ }^{\mathrm{b}}$ Ecole Normale Supérieure, Département de Chimie, UMR CNRS-ENSUPMC 8640 'PASTEUR', 24 rue Lhomond, F-75231, Paris, Cedex 05, France
\end{abstract}

The ferrocenyl compound 2-ferrocenyl-1,1-bis(4-hydroxyphenyl)-but-1-ene (3), is very cytotoxic against breast cancer cells $\left(\mathrm{IC}_{50}=0.44 \mu \mathrm{M}\right.$ against MDA-MB-231). We now report the synthesis of a new series of para- and meta- substituted mono- and di-ferrocenyl phenols [2-ferrocenyl-1-(3-hydroxyphenyl)-1-phenyl-but-1-ene (6), 2-ferrocenyl-1-(3hydroxyphenyl)-1-(4-hydroxyphenyl)-but-1-ene (7), 1,2-di-ferrocenyl-1-(4-hydroxyphenyl)but-1-ene (8), and 1,2-di-ferrocenyl-1-(3-hydroxyphenyl)-but-1-ene (9)] and their electrochemical and biochemical properties, especially in comparison to the previously reported "standard" compounds [2-ferrocenyl-1-(4-hydroxyphenyl)-1-phenyl-but-1-ene (2) and (3)]. We also report the synthesis and characterization of the diphenyl analogue, 2ferrocenyl-1,1-diphenyl-but-1-ene (5). This structure-activity relationship study was motivated by our hypothesis that the cytotoxicity of $\mathbf{3}$ is related to its ability to form a quinone methide structure after two in situ 1-electron oxidations, a process which requires the presence of at least one $p$-phenol. The mono-ferrocenyl compounds (including those previously reported) are reasonably well recognized by the oestrogen receptors $\alpha$ (RBAs $=$ $0.9-9.6 \%)$ and $\beta($ RBAs $=0.28-16.3 \%)$, although the bulkier di-ferrocenyl compounds show very little affinity. In vitro, the cytotoxic effects of the phenolic complexes are related to the positioning of the hydroxyl group (para- superior to meta-), and to the number of ferrocenyl groups (one superior to two), with $\mathrm{IC}_{50}$ values against the MDA-MB-231 cell line ranging 
from 0.44-3.5 $\mu \mathrm{M}$. On the hormone-dependent breast cancer cell line MCF-7, the observed effect seems to be the result of two components, one cytotoxic (antiproliferative) and one estrogenic (proliferative). Electrochemical studies show that only the compounds with a $p$ phenol engage in proton-coupled intramolecular electron transfer.

\section{Introduction}

Although the anti-cancer properties of ferrocene-containing molecules were first studied in the late 1970s, ${ }^{1}$ systematic investigations were not carried out until Köpf-Meyer and Neuse established anti-tumour activity for ferricenium salts in $1984 .^{2}$ This work led to the proposal that ferrocenyl compounds could be activated in the cell by biooxidation, and that both ferricenium and ferrocene- (in a water soluble form) containing compounds could give rise to cytotoxic effects. ${ }^{3}$ To this end ferrocene has been incorporated into water soluble polymers, ${ }^{4}$ tethered to a DNA intercalator, ${ }^{5}$ phosphino compounds, ${ }^{6}$ vitamin $\mathrm{B} 1,{ }^{7}$ and other biomolecules. ${ }^{8}$ Diferrocene compounds ${ }^{9}$ and ferrocene-bearing transition metal ligands, ${ }^{10}$ and a variety of other small ferrocenyl molecules ${ }^{11}$ have also been investigated for anti-cancer activity. Cytotoxic pathways involving DNA have been suggested for the activity of ferrocenyl compounds. ${ }^{12}$

Our laboratory has been studying the effects on the proliferation of breast cancer cells of ferrocenyl phenols, especially those based on the 1,1-diphenyl-but-1-ene motif. ${ }^{13,14}$ Some small organic phenols have been shown to possess oestrogen receptor modulating properties, ${ }^{15}$ and, at higher concentrations, cytotoxic properties. ${ }^{16}$ We have been trying to enhance the cytotoxicity of these types of compounds by the addition of ferrocene, which we hope will be oxidized to ferricenium within the cell. We routinely test the proliferative/antiproliferative effects of our new compounds on MCF-7 (oestrogen receptor positive) and MDA-MB-231 (oestrogen receptor negative) breast cancer cell lines, and have had varying degrees of success. The most promising compounds to date are shown in Chart 1 , all of which exhibit $\mathrm{IC}_{50}$ values at low micromolar or submicromolar concentrations for the MDA-MB-231 cell line. The MCF-7 cell line is the standard for hormone dependant breast cancers, and the proliferative/antiproliferative effects connected to the estrogenicity/antiestrogenicity of molecules at concentrations of $10^{-5}-10^{-7} \mathrm{M}$ are primarily mediated by the oestrogen receptor alpha $(\mathrm{ER} \alpha)$, a nuclear receptor present in these cells. It is known that the dimethyl amino chain of the active metabolite of the breast cancer drug tamoxifen, and also present in compound 1, interacts with ER $\alpha$ in such a way as to prevent 
DNA transcription and cell replication. ${ }^{17}$ The other compounds, lacking the amino chain, would be expected to be estrogenic and proliferative on MCF-7 cells. However, compounds 2-4 have shown antiproliferative effects in both the MCF-7 (ER+, hormone dependent) and MDA-MB-231 (ER-, hormone independent) cell lines, which can be attributed only to the innate cytotoxicity of the molecule. It is important to note that $\mathbf{1 - 4}$ conform to a particular structural motif, where the ferrocenyl group is located on carbon 2 of the but-1-ene group, the phenol group(s) resides on carbon 1 , and a conjugated $\pi$-system exists between the ferrocenyl and phenol groups. It appears that this motif is directly related to the cytotoxic effects shown by these compounds. In a previous study we discovered that compounds 1-4 exhibit cyclic voltammograms characteristic of an interesting structural rearrangement due to an intramolecular electron transfer from the phenolic donor to the electrochemically generated ferricenium acceptor in basic conditions. ${ }^{18}$ We have proposed that the final outcome of this process is the formation of a reactive quinone methide-type (QM) structure after two oneelectron oxidations and the loss of two protons.

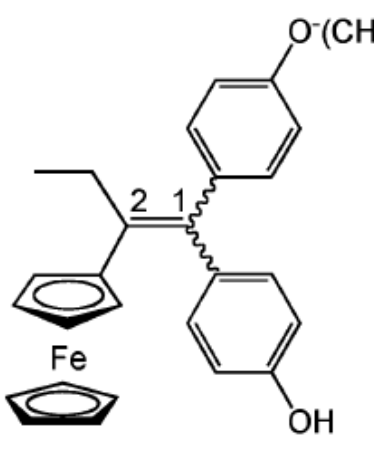

$1 Z+E$

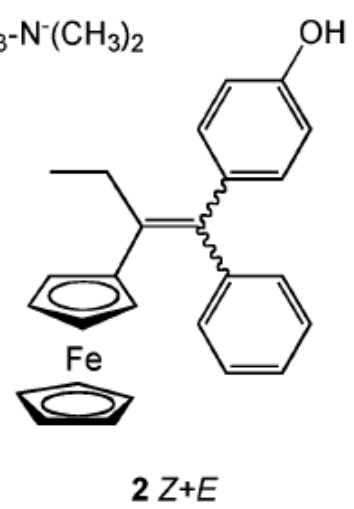

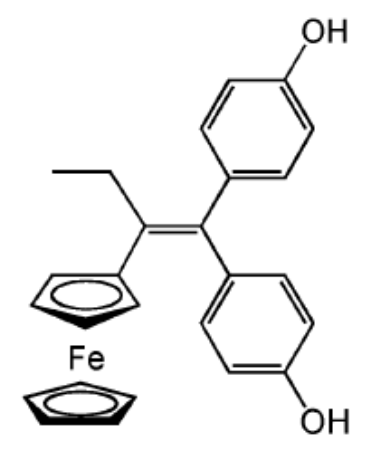

3

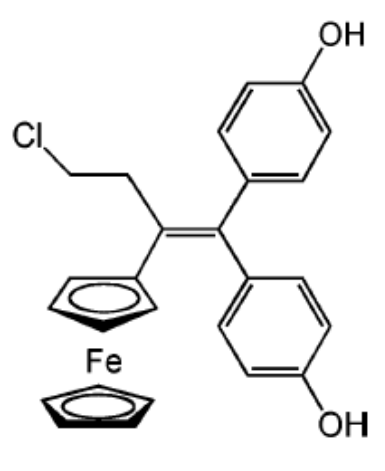

4

Chart 1 Previously reported cytotoxic ferrocenyl phenolic compounds $\mathbf{1},{ }^{14} \mathbf{2},{ }^{19} \mathbf{3},{ }^{13} \mathbf{4}^{20}$

Donor-acceptor assemblies possessing a ferrocene donor have been extensively studied, especially in terms of their non-linear optical properties, ${ }^{21}$ and structural rearrangements as a result of proton- or metal ion-coupled intramolecular electron transfer processes. ${ }^{22}$ However, the possibility of a ferricenium moiety acting as an acceptor has only recently been explored. ${ }^{23,24}$ In particular, a paper by Nishihara and co-workers in Tokyo described the rearrangement of 2-(2-ferrocenylvinyl)hydroquinone to a novel allene quinonoid structure via two one-electron oxidations and intramolecular electron transfer to a ferricenium acceptor. ${ }^{25}$

In order to test our hypothesis that QM-generation is related to the observed cancer cell death, and to further study this novel mechanism of formation, we have synthesized a number 
of new compounds, including those where the hydroxyl group of the phenol is in the metaposition. For example, in compound $\mathbf{6}$, the ferrocene- $\pi$-system-phenol motif is maintained, but it carries a $m$-phenol, so that a QM structure is not accessible. Compound 7 is similar to 6 , with the addition of a $p$-phenol group; in this case we expect that the $m$-phenol will act as a spectator, and the p-phenol might engage in QM formation. We have also synthesized the diferrocenyl $p$-phenol (8), and $m$-phenol (9) to evaluate the importance of the steric effect on the biological efficacy of the compounds. We here report the synthetic, electrochemical, and biochemical results for the new compounds 5-9 shown in Chart 2, and compare these results to those of previously reported compounds $\mathbf{2}$ and $\mathbf{3}$ as appropriate.

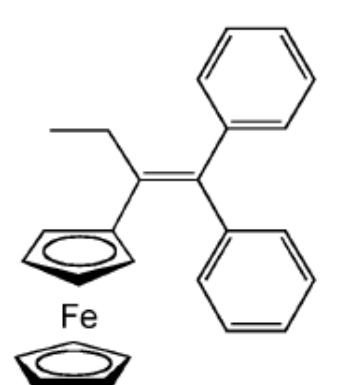

5

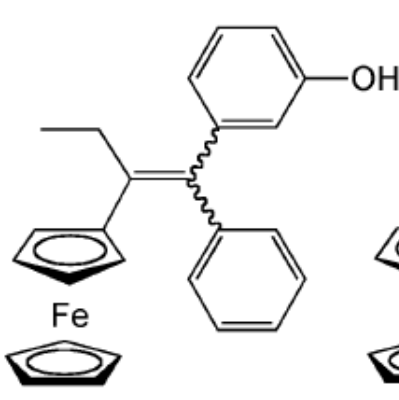

$6 Z+E$

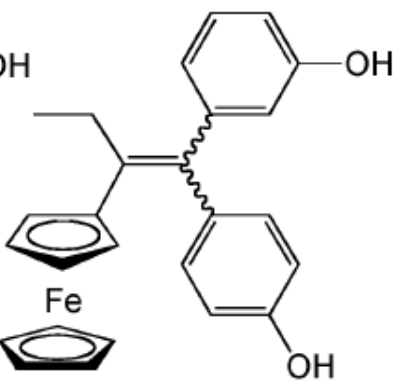

$7 \mathrm{Z}+E$

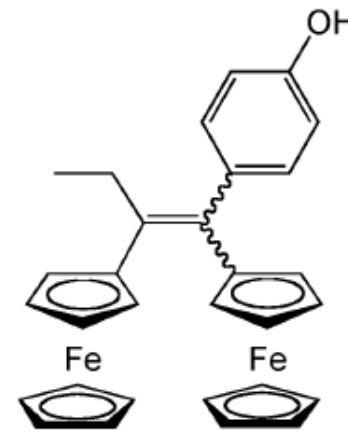

$8 Z+E$

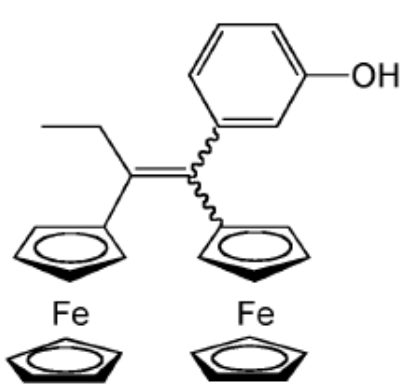

$9 Z+E$

Chart 2 New compounds studied in this report.
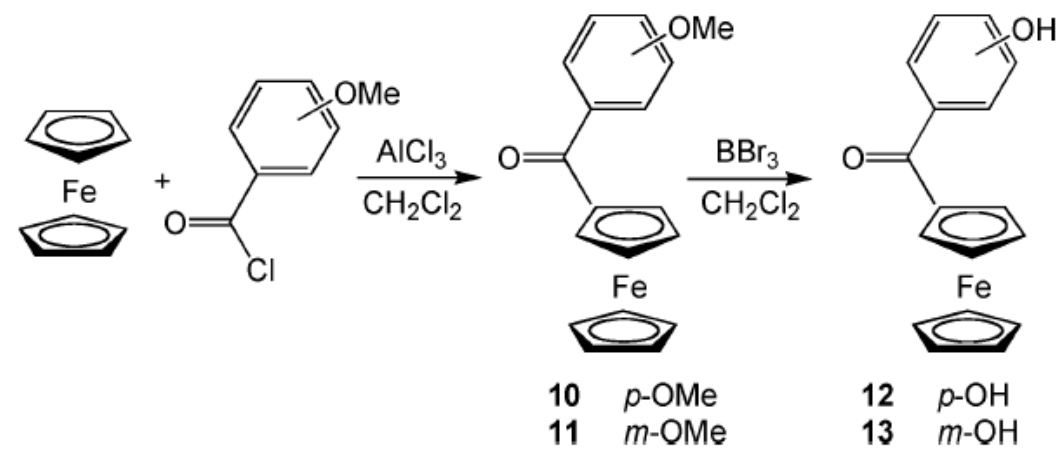
Scheme 1 


\section{Results and discussion}

\section{Synthesis}

The formation of the new compounds 5-9 was generally accomplished by a Friedel-Craft acylation of ferrocene, followed by a McMurry cross-coupling of the ferrocenyl ketone with the appropriate benzophenone. Thus, to synthesize compounds $\mathbf{8}$ and $\mathbf{9}$, we first prepared the known ketone $\mathbf{1 0}^{26}$ (yield 62\%) and the new ketone 11 (yield 82\%) by a Friedel-Craft reaction of the corresponding acyl chlorides with ferrocene, as shown in Scheme 1. The ketones were demethyled with boron tribromide in dichloromethane to give the phenolic compounds $\mathbf{1 2}$ and 13 with yields of $74 \%$ and $76 \%$, respectively. The yield for the formation of $\mathbf{1 2}$ using boron tribromide was higher than the previously reported demethylation of $\mathbf{1 0}$ with aluminium trichloride $(32 \%),{ }^{26}$ but the reaction time was longer (unoptimized $12 \mathrm{~h} \mathrm{vs.} 1.25 \mathrm{~h}$ ). The McMurry reaction of these ketones with propionyl ferrocene 27 gave the cross-coupled diferrocenyl compounds $\mathbf{8}$ and $\mathbf{9}$ with a yield of $39 \%$ for each, Scheme 2.
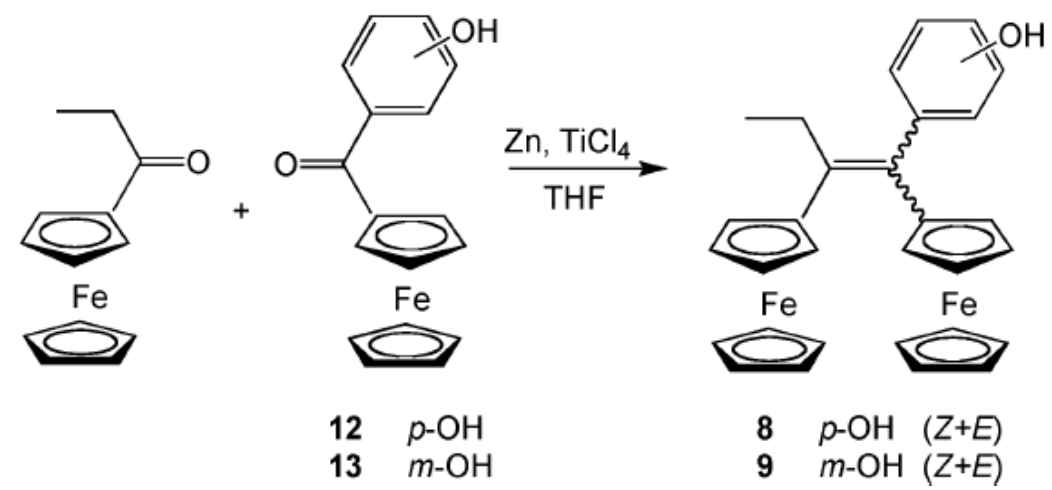

Scheme 2

In the same manner, the McMurry reaction of propionyl ferrocene with dibenzophenone gave compound $\mathbf{5}$ with a yield of $25 \%$, Scheme 3 . This compound was impossible to separate by silica gel column chromatography from the two homo-coupled compounds, due to the similar (low) polarities of these compounds lacking any phenol group. Compound $\mathbf{5}$ was directly isolated by preparative HPLC of the crude mixture. 


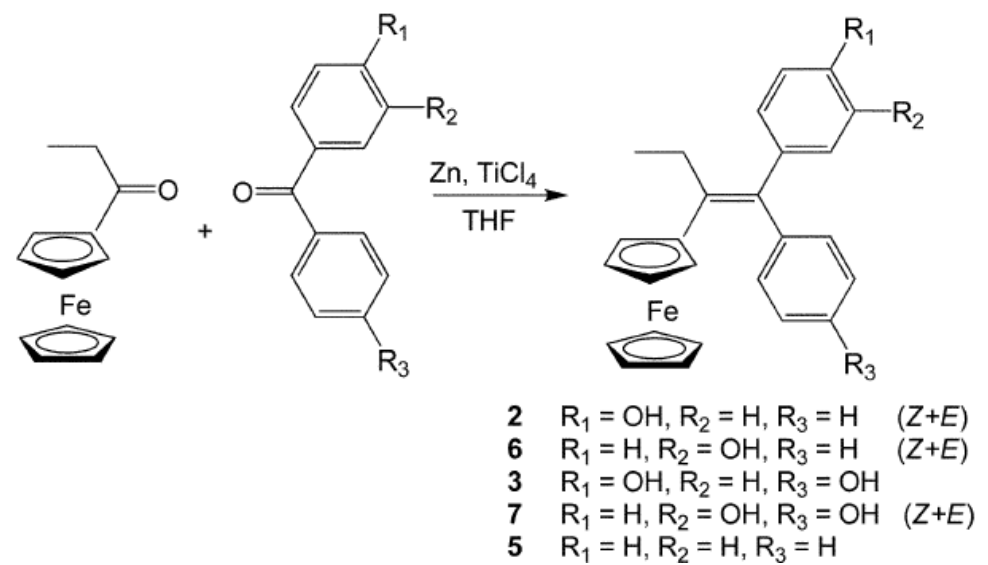

Scheme 3

The mono-ferrocenyl compounds $\mathbf{6}$ and $\mathbf{7}$ were synthesized from propionyl ferrocene by a McMurry reaction using the corresponding phenolic ketones (commercially available for $\mathbf{6}$, and known from the literature for $7^{28,29}$ ) to give a mixture of $Z$ and $E$ isomers in an approximately $1: 1$ ratio.

Compounds 6 and 7 were purified on a silica gel column with dichloromethane or a dichloromethane-acetone solution as the eluent, and then were re-purified via HPLC. $Z$ and $E$ isomers of compounds $\mathbf{6}$ and 7 were impossible to separate, while isomers of compounds 8 and 9 were partially separated but rapidly (within a few hours) isomerised to give a $1: 1$ mixture of $Z$ and $E$ isomers.

\section{Cyclic voltammetry.}

Compounds 5-9 were studied by cyclic voltammetry in methanol and methanol-pyridine solutions. In methanolic solutions, all of the compounds gave rise to the expected reversible ferrocene/ferricenium redox waves, with 5, 6, and $\mathbf{7}$ giving rise to one wave, and compounds 8 and 9 displaying 2 one-electron waves. The separation of observed redox potentials $\left(\Delta E^{\circ}\right)$ for the two waves generated by compounds $\mathbf{8}$ and $\mathbf{9}$ was not significantly different: 162 and $159 \mathrm{mV}$, respectively. These values are slightly lower than that of trans- $\mathrm{Fc}(\mathrm{CH}=\mathrm{CH}) \mathrm{Fc}$, which has been reported as $170 \mathrm{mV}$ in $\mathrm{CH}_{2} \mathrm{Cl}_{2},{ }^{30}$ although the disparity can be accounted for by the decrease in Coulombic repulsion due to the solvent cage. The presence of two oneelectron oxidation waves instead of one two-electron oxidation wave signifies a stabilization of the mixed valence species $\left(\mathrm{Fc}^{\mathrm{II}}, \mathrm{Fc}^{\mathrm{III}}\right)$, the extent of which is often expressed as the comproportionation constant, $K c$. For $\mathbf{8}$ and $\mathbf{9}, K c=550$ and 490, respectively, (using the equation $\left.\Delta E^{\circ}{ }^{\prime}=(R T / F) \ln K c\right)^{30}$ and thus these compounds can be considered Robin-Day 
Class II mixed-valent complexes, with moderate electron coupling between the oxidized and reduced centres. ${ }^{31}$ Oxidation potentials $v s$. SCE are given in Table 1.

Table 1 Formal oxidation and redox potentials for compounds 2, 5-9 vs. SCE. ${ }^{\text {a }}$

\begin{tabular}{|c|c|c|c|c|}
\hline & Solvent & $E_{\mathrm{p}, \mathrm{o}}(\mathrm{Fc}) E_{\mathrm{p}, \mathrm{o}}($ other $)$ & $E^{\circ}\left(\mathrm{Fc} / \mathrm{Fc}^{+}\right)^{c}$ & $\begin{array}{l}\text { Electron } \\
\text { transfer? }\end{array}$ \\
\hline \multirow[t]{4}{*}{$2^{b}$} & $\mathrm{MeOH}$ & $0.397(2)$ & $0.357(2)$ & Yes \\
\hline & & $0.97(1)^{d}$ & & \\
\hline & MeOH-py & $0.423(4)^{d, e}$ & $d$ & \\
\hline & & $0.510(3)^{c}$ & & \\
\hline \multirow[t]{2}{*}{$5^{b}$} & $\mathrm{MeOH}$ & $0.421(3)$ & $0.380(3)$ & No \\
\hline & MeOH-py & $0.442(3)$ & $0.400(3)$ & \\
\hline \multirow[t]{2}{*}{6} & $\mathrm{MeOH}$ & $0.403(3)$ & $0.365(3)$ & No \\
\hline & MeOH-py & $0.408(3)$ & $0.375(3)$ & \\
\hline \multirow[t]{4}{*}{7} & $\mathrm{MeOH}$ & $0.418(3)$ & $0.386(3)$ & Yes \\
\hline & & $1.01(1)^{d}$ & & \\
\hline & MeOH-py & $0.43(1)^{d, e}$ & $d$ & \\
\hline & & $0.528(3)^{d}$ & & \\
\hline \multirow[t]{4}{*}{8} & $\mathrm{MeOH}$ & $0.334(3) 0.504(3)$ & $0.300(3) 0.462(3)^{d}$ & Yes \\
\hline & МeOH-py & $0.34(1)^{d, e}$ & $0.649(3)$ & \\
\hline & & $0.444(3)^{d}$ & & \\
\hline & & $0.703(3)$ & & \\
\hline \multirow[t]{2}{*}{9} & $\mathrm{MeOH}$ & $0.344(3) 0.503(3)$ & $0.311(3) 0.470(3)$ & Yes \\
\hline & МeOH-py & $0.346(3) 0.523(3)$ & $0.313(3) 0.488(3)$ & \\
\hline
\end{tabular}

In terms of the interaction of the electrochemically generated cations with the added pyridine, the compounds can be divided into two categories. For compounds 5, 6 and 9, which do not possess $p$-phenols, no significant difference in the electrochemical behaviour was observed upon the addition of pyridine, Fig. 1a,b. Conversely, for those compounds carrying a p-phenol, $\mathbf{7}$ and $\mathbf{8}$, the addition of pyridine altered the CV substantially, especially in view of the reversibility of the ferrocene redox couple and the emergence of a new peak slightly higher in potential than the ferrocene oxidation. We have previously observed this 
electrochemical behaviour for compounds 1-4, and have attributed it to an intramolecular electron transfer from the organic skeleton to the ferricenium moiety coupled with deprotonation of the phenol by pyridine, eventually resulting in a QM structure. ${ }^{18}$ While the electrochemical behaviour of compound $\mathbf{7}$ is similar to that of compounds $\mathbf{1 - 4}$, that of 8 is complicated by the presence of a second ferrocenyl group. The voltammetry of $\mathbf{8}$ in the presence and absence of pyridine shows that the intramolecular electron transfer leading ultimately to the quinone methide formation occurs at the level of the first oxidation wave. Since the ferricinium group attached to the $\mathrm{C} 1$ carbon atom of the central double-bond (see Scheme 4) cannot be conjugated directly to the phenol moiety, one must conclude that the intramolecular phenol oxidation occurs via the $\mathrm{C} 2$ ferricinium. Yet since both ferrocene units give rise to a significant electron transfer interaction, one cannot strictly differentiate between the two under electrochemical conditions. Nevertheless, this suggests that the $\mathrm{C} 1$ ferrocene moiety is oxidized after the electron transfer to the $\mathrm{C} 2$ ferricenium moiety and rearrangement to the quinonoid, as shown in Scheme 4.
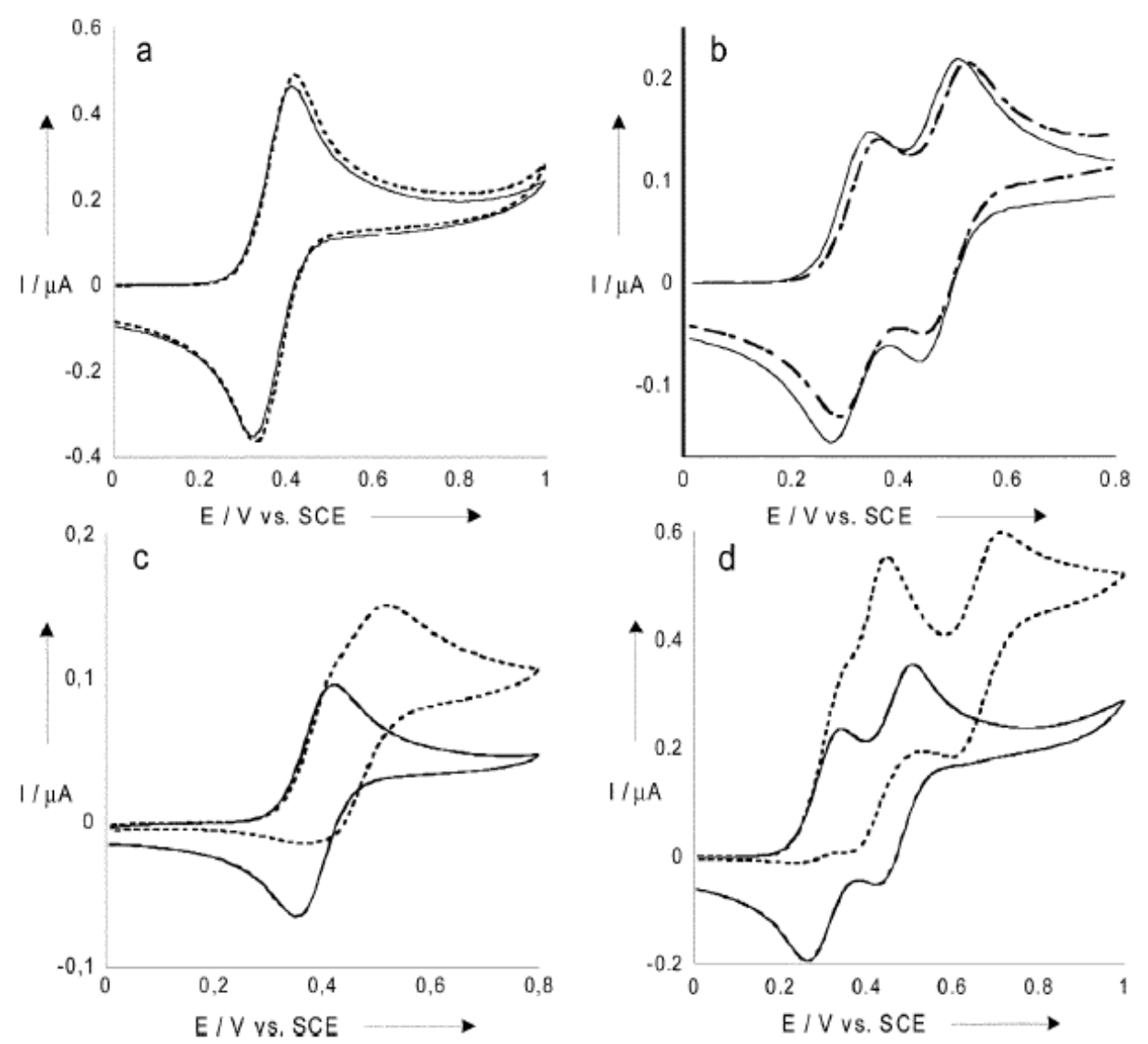

Fig. 1 Cyclic voltammograms of 6 (a), 9 (b), 7 (c), and 8 (d) in $0.1 \mathrm{M} \mathrm{Bu}_{4} \mathrm{NBF}_{4} / \mathrm{MeOH}$ in absence (solid line) and presence (dashed line) of pyridine in a $1: 6$ volume ratio. Scan rate 

published in reference 18 .

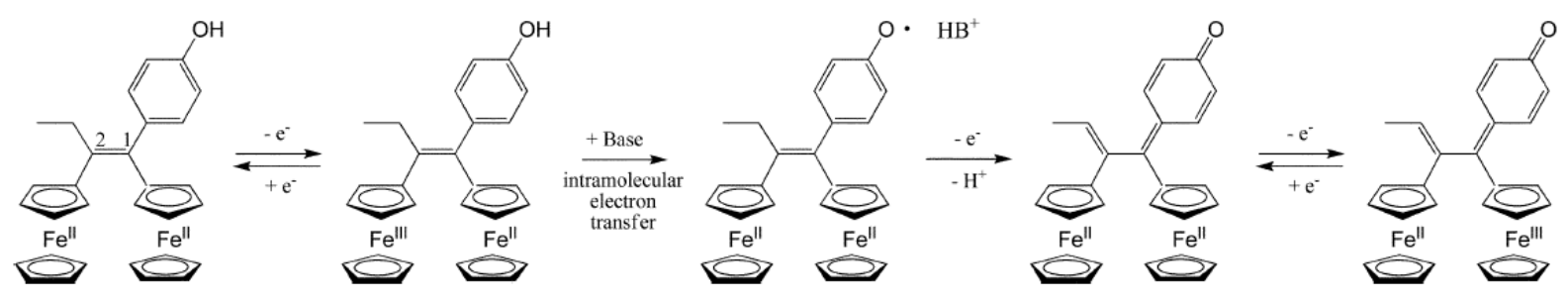

Scheme 4

Thus, the electronic environment around the $\mathrm{C} 1$ ferrocene is expected to be substantially changed when it is finally oxidized. This is confirmed by the large anodic shift of its oxidation potential in $\mathrm{MeOH}-$ py compared to that in $\mathrm{MeOH}(0.703$ vs. $0.504 \mathrm{~V}$, respectively). The influence of nearby quinonoids on the destabilization of the ferricenium cation has been previously observed, and has been attributed to partial electron donation from the ferrocene to the quinonoid moiety. ${ }^{24}$

a)
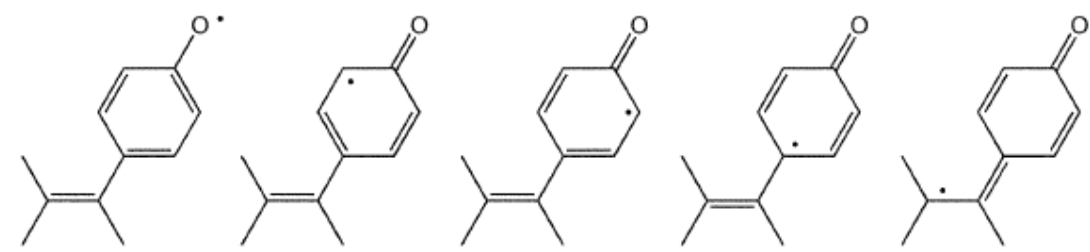

b)
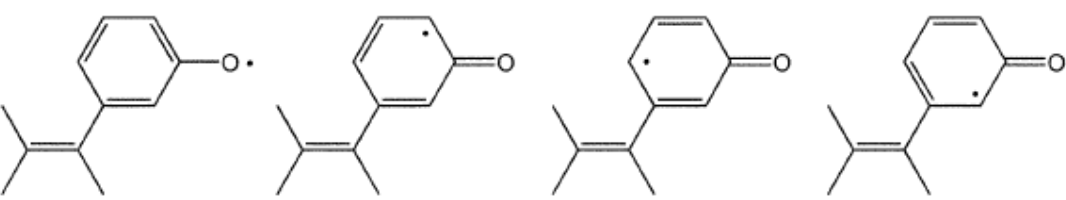

Chart 3 Electron delocalization on a) $p$-phenol and b) $m$-phenol.

We asked ourselves why only the compounds possessing a $p$-phenol engaged in electron transfer, given the ostensible similarities in molecular and electronic structure between these compounds. We have previously shown in these types of compounds that in the initial cation the radical is localized on the ferricenium group, and that there is little electronic delocalization with the phenol group prior to deprotonation. ${ }^{18}$ This is supported by the comparison of the ferrocene oxidation potentials in $\mathrm{MeOH}$ for $2(0.397 \mathrm{~V}), \mathbf{5}(0.421 \mathrm{~V})$, and $\mathbf{6}$ $(0.403 \mathrm{~V})$, which show little difference, and hence little stabilization of the radical by the phenol group. The answer may be found instead in considering the stability of the neutral 
radical species which is generated after electron transfer and deprotonation. By drawing the canonical structures contributing to the delocalization of the radical, Chart 3, we can see that the $p$-phenol is able to delocalize the radical onto the $\mathrm{C} 1, \mathrm{C} 2$-alkene, while the radical in the $m$-phenol can only be delocalized over the phenol itself. Thus, complexes with a parasubstituted phenol benefit from greater resonance stabilization and are therefore energetically more accessible intermediates than their $m$-phenol analogues.

\section{Biochemistry}

RBA and lipophilicity values. The affinities for the oestrogen receptor of the newly synthesized complexes were measured on the two isoforms of the oestrogen receptor, ER $\alpha$ and ER $\beta$, and are reported as relative binding affinity (RBA) values in Table 2. All the compounds were recognized by both forms of the ER but the RBA values are quite different ranging from high (about 5\%) to low values (less than 1\%). In the mono-ferrocenyl series the change of the $\mathrm{OH}$ substituent from the para- to the meta-position induced only a slight decrease of the RBA value for the alpha form of the estrogen receptor (4.6\% versus $3.6 \%$ for the monophenols, $9.6 \%$ versus $5.4 \%$ for the diphenols). On the contrary, the presence of an $m$ $\mathrm{OH}$ substituent dramatically decreased the affinity of the complexes for the beta form of the oestrogen receptor with an RBA ratio $\mathrm{ER} \beta / \mathrm{ER} \beta$ of 21 for the monophenols $\mathbf{2}$ and $\mathbf{6}$, and 6.8 for the diphenols 3 and 7. Quite surprisingly, the diphenyl complex $\mathbf{5}$, i.e. the compound with no $\mathrm{OH}$, has a non-zero RBA value of $0.9 \%$. A similar RBA value $(0.8 \%)$ was previously reported for the corresponding organic molecule, 1,1,2-triphenylbut-1-ene. ${ }^{32}$ Finally, the RBA values found for the di-ferrocenyl derivatives are quite low for both forms of the oestrogen receptor. This is probably due to the presence of the two ferrocenyl units which are bulkier than a phenyl substituent. Regarding the $\log P_{\mathrm{o} / \mathrm{w}}$ values, the change of the $\mathrm{OH}$ group from the para- to the meta- position plays no role, and, as expected, the complexes with no hydroxyl groups or with two ferrocenyl substituents are more hydrophobic with $\log P_{\mathrm{o} / \mathrm{w}}$ values around 6.4 .

\section{Effect of the compounds on the growth of breast cancer cells.}

The effect of these complexes at a concentration of $1 \times 10^{-6} \mathrm{M}$ was studied on hormoneindependent (MDA-MB-231) and hormone-dependent (MCF-7) breast cancer cells and the results are displayed in Fig. 2. The antiproliferative effect observed on the hormoneindependent breast cancer cells can be attributed only to a cytotoxic effect potentially induced 
by the ferrocenyl unit. On these cells, complexes 6, 8, and 9 show the lowest antiproliferative effects with $\mathrm{IC}_{50}$ values between 2.7 and $3.5 \mu \mathrm{M}$ (Table 2); compounds 2 and 7 are more cytotoxic ( $\mathrm{IC}_{50}$ values around $1 \mu \mathrm{M}$ ); while 3 with an $\mathrm{IC}_{50}$ of $0.44 \mu \mathrm{M}$ is the most cytotoxic of the series. These results show that the repositioning of one $\mathrm{OH}$ group from the para- to the meta-position significantly lowers the cytotoxicity of the complex (ratio of $\mathrm{IC}_{50}$ values of 6 versus 2 and 7 versus 3 being respectively 2.4 and 2.3). The presence of a second ferrocenyl unit decreases the cytotoxicity of the complexes ( $\mathrm{IC}_{50}$ of $2.8 \mu \mathrm{M}$ for $\mathbf{8}$ and $1.13 \mu \mathrm{M}$ for $2 ; 3.5$ $\mu \mathrm{M}$ for $\mathbf{9}$ and $2.7 \mu \mathrm{M}$ for $\mathbf{6}$ ); here also the complex with a $m$-OH group is less cytotoxic than the one with a $p-\mathrm{OH}$. Finally, as expected, estradiol has no effect on these cells with no ER $\alpha$.

On the contrary, the effect observed on hormone-dependent breast cancer cells is the result of the estrogenic (proliferative) effect expected for these compounds that all show an affinity for the alpha form of the ER minus its cytotoxic component observed on the hormoneindependent cancer cells. At a concentration of $1 \mu \mathrm{M}$ and in a medium without phenol red, which is best suited to the expression of the estrogenic component of a molecule, only the most cytotoxic complexes $\mathbf{2}$ and $\mathbf{3}$ are able to reverse the strong estrogenic effect shown by estradiol. As expected complexes $\mathbf{5}$ and $\mathbf{6}$ which are the less cytotoxic on the MDA-MB-231 cells show a clear proliferative effect.

\section{Experimental}

\section{General remarks}

The synthesis of all compounds was performed under an argon atmosphere, using standard Schlenk techniques. Anhydrous THF was obtained by distillation from sodiumbenzophenone. Thin layer chromatography was performed on silica gel 60 GF254. Infrared spectra were obtained on an IRFT BOMEM Michelson-100 spectrometer equipped with a DTGS detector as a $\mathrm{KBr}$ plate. ${ }^{1} \mathrm{H}$ and ${ }^{13} \mathrm{C}$ NMR spectra were recorded on a $300 \mathrm{MHz}$ Bruker spectrometer. Mass spectrometry was performed with a Nermag R 10-10C spectrometer. High resolution mass spectrometry (HRMS) was performed on a JEOL MS 700 instrument. Melting points were measured with a Kofler device. Elemental analyses were performed by the microanalysis service of CNRS at Gif sur Yvette. The semi-preparative HPLC separations were performed on a Shimadzu apparatus with a Kromasil C18 column (length of $25 \mathrm{~cm}$, diameter of $2 \mathrm{~cm}$, particles size of $10 \mu \mathrm{m})$. 
Cyclic voltammograms were obtained utilizing an Autolab PG-Stat20 potentiostat, driven by GPES software (General Purpose Electrochemical System, Version 4.8, EcoChemie B.V., Utrecht, the Netherlands), a platinum wire counter electrode, a $500 \mu \mathrm{M}$ platinum disc working electrode, and an aqueous standard calomel reference electrode. Analyte solutions were 1-2 $\mathrm{mM}$ in $\mathrm{MeOH}$ with $0.1 \mathrm{M} \mathrm{Bu}_{4} \mathrm{NBF}_{4}$ supporting electrolyte. Solvent ratios were $6: 1 \mathrm{MeOH}$ : py, except for compound 5, where the ratio was $3: 1 \mathrm{MeOH}:$ py. Unfortunately, the insolubility of these compounds in water prevented the preparation of aqueous samples at suitable concentrations. Solvents were spectrometric grade and used as received.

\section{Synthesis and characterization}

Compound 10. The synthesis is described in reference 26.

Compound 11. Ferrocene (10.2 g, $54.8 \mathrm{mmol})$ was dissolved in dry dichloromethane (400 $\mathrm{mL})$. Aluminium trichloride $(7.30 \mathrm{~g}, 54.8 \mathrm{mmol})$ was added in portions over $15 \mathrm{~min}$. Then, $m$ anisoyl chloride $(7.79 \mathrm{~g}, 45.7 \mathrm{mmol})$ was added slowly over $20 \mathrm{~min}$ and the stirring was continued overnight. The solution was slowly poured into a mixture of water and ice and decanted. The aqueous layer was extracted with dichloromethane and the combined organic layers were washed with water, dried over magnesium sulfate and concentrated under reduced pressure. The mixture was chromatographed on a silica gel column with a solution of dichloromethane-petroleum ether $50: 50$ as the eluent. The pure product $\mathbf{1 1}$ was obtained as an oil (11.92 g, 82\%). ${ }^{1} \mathrm{H}$ NMR (300 MHz, $\left.\mathrm{CDCl}_{3}\right) \delta 3.81\left(\mathrm{~s}, 3 \mathrm{H}, \mathrm{OCH}_{3}\right), 4.14(\mathrm{~s}, 5 \mathrm{H}, \mathrm{Cp})$, $4.51\left(\mathrm{t}, J=1.9 \mathrm{~Hz}, 2 \mathrm{H}, \mathrm{C}_{5} \mathrm{H}_{4}\right), 4.85\left(\mathrm{t}, J=1.9 \mathrm{~Hz}, 2 \mathrm{H}, \mathrm{C}_{5} \mathrm{H}_{4}\right), 7.02$ (ddd, $J=8.0,3.6,1.0 \mathrm{~Hz}$, $\left.1 \mathrm{H}, \mathrm{H}_{\text {arom }}\right), 7.30$ (t, $\left.J=8.0 \mathrm{~Hz}, 1 \mathrm{H}, \mathrm{H}_{\text {arom }}\right), 7.35$ (m, $\left.1 \mathrm{H}, \mathrm{H}_{\text {arom }}\right), 7.42$ (dt, $J=8.0,1.0 \mathrm{~Hz}, 1$ $\left.\mathrm{H}, \mathrm{H}_{\text {arom }}\right) .{ }^{13} \mathrm{C} \mathrm{NMR}\left(\mathrm{CDCl}_{3}\right) \delta 55.5\left(\mathrm{OCH}_{3}\right), 70.2(5 \mathrm{CH} \mathrm{Cp}), 71.5\left(2 \mathrm{CH} \mathrm{C}_{5} \mathrm{H}_{4}\right), 72.6(2 \mathrm{CH}$ $\left.\mathrm{C}_{5} \mathrm{H}_{4}\right), 78.1\left(\mathrm{C} \mathrm{C}_{5} \mathrm{H}_{4}\right), 113.1\left(\mathrm{CH}_{\text {arom }}\right), 117.6\left(\mathrm{CH}_{\text {arom }}\right), 120.6\left(\mathrm{CH}_{\text {arom }}\right), 129.2\left(\mathrm{CH}_{\text {arom }}\right), 141.1$ (C), 159.5 (C), 198.9 (CO). IR: 3098, 2938, $2836\left(\mathrm{CH}_{3}\right), 1638$ (CO) $\mathrm{cm}^{-1}$. MS (CI, $\left.\mathrm{NH}_{3}\right) \mathrm{m} / z$ : $321[\mathrm{MH}]^{+\bullet}$.

Demethylation of compounds 10 and 11. Compound 10 or 11 (3.2 g, $10 \mathrm{mmol}$ ), was dissolved in dry dichloromethane $(60 \mathrm{~mL})$ at $0{ }^{\circ} \mathrm{C}$ and boron tribromide $(2.84 \mathrm{~mL}, 30 \mathrm{mmol})$ was added. The mixture was stirred overnight at room temperature. The solution was slowly poured into a mixture of water and ice and extracted with ethyl acetate. The combined organic layers were washed with water, dried over magnesium sulfate and concentrated under reduced pressure. The mixture was chromatographed on a silica gel column with dichloromethane as 
the eluent to yield the phenol compounds which were recrystallized from an ether-pentane solution.

Formation of compound 12, anisoylferrocene. This compound is described in the literature and was synthesized via the demethylation of $\mathbf{1 0}$ using $\mathrm{AlCl}_{3}$ (yield 32\%) in place of $\mathrm{BBr}_{3}$, the latter being used in our case. Compound $\mathbf{1 2}$ was obtained as a dark orange solid ( $2.24 \mathrm{~g}, 74 \%$ yield). The characteristics were identical to those described in the literature (mp $\left.186{ }^{\circ} \mathrm{C}, 186-188{ }^{\circ} \mathrm{C},{ }^{26} 190-191{ }^{\circ} \mathrm{C}^{27}\right)$. Anal. Calcd for $\mathrm{C}_{17} \mathrm{H}_{14} \mathrm{FeO}_{2}$ : C, 66.69; H, 4.60. Found: C, 66.77; H, 4.45.

Formation of compound 13. This compound was obtained as an orange dark solid (2.3 g, $76 \%$ yield). ${ }^{1} \mathrm{H}$ NMR (300 MHz, $\left.\mathrm{CDCl}_{3}\right) \delta 4.12$ (s, $\left.5 \mathrm{H}, \mathrm{Cp}\right), 4.53\left(\mathrm{~s}, 2 \mathrm{H}, \mathrm{C}_{5} \mathrm{H}_{4}\right), 4.87(\mathrm{~s}, 2 \mathrm{H}$, $\left.\mathrm{C}_{5} \mathrm{H}_{4}\right), 7.02$ (d, $\left.J=6.8 \mathrm{~Hz}, 1 \mathrm{H}, \mathrm{H}_{\text {arom }}\right), 7.12-7.41$ (m, $\left.3 \mathrm{H}, \mathrm{H}_{\text {arom }}\right), 7.45$ (s, $\left.1 \mathrm{H}, \mathrm{OH}\right) .{ }^{13} \mathrm{C} \mathrm{NMR}$ $\left(\mathrm{CDCl}_{3}\right) \delta 70.4(5 \mathrm{CH} \mathrm{Cp}), 71.7\left(2 \mathrm{CH} \mathrm{C}_{5} \mathrm{H}_{4}\right), 73.0\left(2 \mathrm{CH} \mathrm{C}_{5} \mathrm{H}_{4}\right), 77.7\left(\mathrm{C} \mathrm{C}_{5} \mathrm{H}_{4}\right), 115.1$ $\left(\mathrm{CH}_{\text {arom }}\right), 119.2\left(\mathrm{CH}_{\text {arom }}\right), 120.3\left(\mathrm{CH}_{\text {arom }}\right), 129.4\left(\mathrm{CH}_{\text {arom }}\right), 140.8(\mathrm{C}), 156.4(\mathrm{C}), 200.3(\mathrm{CO})$. IR: $3423(\mathrm{OH}), 2928,2856\left(\mathrm{CH}_{3}\right), 1614(\mathrm{CO}) \mathrm{cm}^{-1}$. MS (CI, NH$)_{3} \mathrm{~m} / z: 307[\mathrm{MH}]^{+\bullet}, 324[\mathrm{M}+$ $\left.\mathrm{NH}_{4}\right]^{+}$. Anal. Calcd for $\mathrm{C}_{17} \mathrm{H}_{14} \mathrm{FeO}_{2}$ : C, 66.69; H, 4.60. Found: C, 66.83; H, 4.57.

\section{General procedure for formation of compounds 5, 6, 7, 8, 9.}

Titanium tetrachloride $(3.6 \mathrm{~mL}, 33 \mathrm{mmol})$ was added dropwise to a suspension of zinc powder $(4 \mathrm{~g}, 61 \mathrm{mmol})$ in $80 \mathrm{~mL}$ of dry $\mathrm{THF}$ at $0{ }^{\circ} \mathrm{C}$. The mixture was heated at reflux for 2 h. A second solution was prepared by dissolving propionyl ferrocene $(2.42 \mathrm{~g}, 10 \mathrm{mmol})$ and the corresponding ketones $(10 \mathrm{mmol})$ in $50 \mathrm{ml}$ of dry THF. This latter solution was added dropwise to the first solution and then the reflux was continued for $2 \mathrm{~h}$. After cooling to room temperature, the mixture was stirred with water and dichloromethane. The mixture was acidified with diluted hydrochloric acid until the dark colour disappeared and was decanted. The aqueous layer was extracted with dichloromethane and the combination of organic layers was dried over magnesium sulfate. After concentration under reduced pressure, the crude product was chromatographed on a silica gel column with dichloromethane or a solution of dichloromethane-acetone $95: 5$ as the eluent (5 excepted). For the biological tests, each products were re-purified on semi-preparative HPLC with acetonitrile-water or acetonitrile as the eluent to give pure $\mathbf{5}, \mathbf{6}, \mathbf{7}, \mathbf{8}$, and $\mathbf{9}$. The isomers, if any, were either inseparable, or partially separated but remixed in the same flask (because of rapid isomerisation) before evaporation of acetonitrile under reduced pressure. The mixture was extracted with 
dichloromethane and water, decanted, dried over magnesium sulfate, and concentrated under reduced pressure. The mixture of isomers, if any, was recrystallized in the appropriate solvent.

2-Ferrocenyl-1,1-di-phenyl-but-1-ene, 5. The reaction was performed with $1.82 \mathrm{~g}$ (10 mmol) of commercially available benzophenone. The crude product was directly purified on HPLC with acetonitrile as eluent to yield 5 as an orange solid (0.96 g, 25\% yield). The compound was recrystallized from acetonitrile. Mp: $160{ }^{\circ} \mathrm{C} .{ }^{1} \mathrm{H}$ NMR $\left(300 \mathrm{MHz}, \mathrm{CDCl}_{3}\right) \delta$ 0.97 (t, $J=7.5 \mathrm{~Hz}, 3 \mathrm{H}, \mathrm{CH}_{3}$ ), 2.50 (q, $J=7.5 \mathrm{~Hz}, 2 \mathrm{H}, \mathrm{CH}_{2}$ ), 3.80 (t, $J=1.9 \mathrm{~Hz}, 2 \mathrm{H}, \mathrm{C}_{5} \mathrm{H}_{4}$ ), $3.99\left(\mathrm{t}, J=1.9 \mathrm{~Hz}, 2 \mathrm{H}, \mathrm{C}_{5} \mathrm{H}_{4}\right), 4.04(\mathrm{~s}, 5 \mathrm{H}, \mathrm{Cp}), 6.95-7.36\left(\mathrm{~m}, 10 \mathrm{H}, \mathrm{H}_{\text {arom }}\right) .{ }^{13} \mathrm{C} \mathrm{NMR}$ $\left(\mathrm{CDCl}_{3}\right) \delta 15.5\left(\mathrm{CH}_{3}\right), 27.8\left(\mathrm{CH}_{2}\right), 68.2\left(2 \mathrm{CH} \mathrm{C}_{5} \mathrm{H}_{4}\right), 69.2(5 \mathrm{CH} \mathrm{Cp}), 69.3\left(2 \mathrm{CH} \mathrm{C}_{5} \mathrm{H}_{4}\right), 86.5$ $\left(\mathrm{C} \mathrm{C}_{5} \mathrm{H}_{4}\right), 126.2\left(2 \mathrm{CH}_{\text {arom }}\right), 128.2\left(2 \mathrm{CH}_{\text {arom }}\right), 128.3\left(2 \mathrm{CH}_{\text {arom }}\right), 129.3\left(2 \mathrm{CH}_{\text {arom }}\right), 129.8$ (2 $\left.\mathrm{CH}_{\text {arom}}\right), 137.4$ (C), 138.0 (C), 144.5 (C), 144.7 (C). IR: 3078, 3044, 2963, 2930, $2869\left(\mathrm{CH}_{2}\right.$, $\left.\mathrm{CH}_{3}\right) \mathrm{cm}^{-1}$. MS (EI, $\left.70 \mathrm{eV}\right) \mathrm{m} / \mathrm{z:} 392[\mathrm{M}]^{+\bullet}, 363[\mathrm{M}-\mathrm{Et}]^{+}, 327[\mathrm{M}-\mathrm{Cp}]^{+}, 121[\mathrm{CpFe}]^{+}$. HRMS (EI, $70 \mathrm{eV}, \mathrm{C}_{26} \mathrm{H}_{24} \mathrm{Fe}: \mathrm{M}^{+}$) calcd: 392.1228, found: 392.1218. Anal. Calcd for $\mathrm{C}_{26} \mathrm{H}_{24} \mathrm{Fe}$ : C, 79.59; H, 6.16. Found: C, 79.37; H, 6.11.

2-Ferrocenyl-1-(3-hydroxyphenyl)-1-phenyl-but-1-ene, 6. The reaction was performed with $1.98 \mathrm{~g}(10 \mathrm{mmol})$ of commercially available 3-hydroxybenzophenone. The crude product was chromatographed with $\mathrm{CH}_{2} \mathrm{Cl}_{2}$ as eluent. The compound was purified on HPLC with acetonitrile-water $80: 20$ as eluent to yield 6 as an orange solid $(0.753 \mathrm{~g}, 19 \%$ yield). The mixture of isomers was recrystallized from heptane. ${ }^{1} \mathrm{H} \mathrm{NMR}\left(300 \mathrm{MHz}, \mathrm{CDCl}_{3}\right) \delta 1.03$ and $1.07\left(\mathrm{t}, J=7.4 \mathrm{~Hz}, 3 \mathrm{H}, \mathrm{CH}_{3}\right), 2.56$ and $2.60\left(\mathrm{q}, J=7.4 \mathrm{~Hz}, 2 \mathrm{H}, \mathrm{CH}_{2}\right), 3.87$ and $3.94(\mathrm{t}, J=$ $\left.1.9 \mathrm{~Hz}, 2 \mathrm{H}, \mathrm{C}_{5} \mathrm{H}_{4}\right), 4.07$ and 4.09 (t, $J=1.9 \mathrm{~Hz}, 2 \mathrm{H}, \mathrm{C}_{5} \mathrm{H}_{4}$ ), 4.11 and 4.12 (s, $\left.5 \mathrm{H}, \mathrm{Cp}\right), 4.53$ and $4.62(\mathrm{~s}, 1 \mathrm{H}, \mathrm{OH}), 6.54-6.88\left(\mathrm{~m}, 3 \mathrm{H}, \mathrm{H}_{\text {arom }}\right), 7.06-7.28\left(\mathrm{~m}, 5 \mathrm{H}, \mathrm{H}_{\text {arom }}\right), 7.33(\mathrm{t}, J=7.5$ $\left.\mathrm{Hz}, 1 \mathrm{H}, \mathrm{H}_{\text {arom }}\right) \cdot{ }^{13} \mathrm{C} \mathrm{NMR}\left(\mathrm{CDCl}_{3}\right) \delta 15.5$ and $15.6\left(\mathrm{CH}_{3}\right), 27.8\left(\mathrm{CH}_{2}\right), 68.2$ and $68.3(2 \mathrm{CH}$ $\left.\mathrm{C}_{5} \mathrm{H}_{4}\right), 69.2$ (5 CH Cp), $69.3\left(2 \mathrm{CH} \mathrm{C}_{5} \mathrm{H}_{4}\right), 86.3\left(\mathrm{C} \mathrm{C}_{5} \mathrm{H}_{4}\right), 113.2\left(\mathrm{CH}_{\text {arom }}\right), 116.2$ and 116.6 $\left(\mathrm{CH}_{\text {arom }}\right), 121.9$ and $122.5\left(\mathrm{CH}_{\text {arom }}\right), 126.2\left(\mathrm{CH}_{\text {arom }}\right), 128.2$ and $128.3\left(2 \mathrm{CH}_{\text {arom }}\right), 129.3$ and $129.8\left(2 \mathrm{CH}_{\text {arom }}\right), 129.4$ and $129.5\left(\mathrm{CH}_{\text {arom }}\right), 137.4(\mathrm{C}), 137.5$ and $137.6(\mathrm{C}), 144.3$ and 144.4 (C), 146.2 and 146.3 (C), 155.4 (C). IR: 3498, $3422(\mathrm{OH}), 3078,3052,3021,2959,2927$, $2870\left(\mathrm{CH}_{2}, \mathrm{CH}_{3}\right) \mathrm{cm}^{-1}$. MS (EI, $\left.70 \mathrm{eV}\right) \mathrm{m} / \mathrm{z}: 408\left[\mathrm{M}^{+\bullet}, 379[\mathrm{M}-\mathrm{Et}]^{+}, 343[\mathrm{M}-\mathrm{Cp}]^{+}, 121\right.$ [CpFe] $]^{+}$. HMRS (EI, $70 \mathrm{eV}, \mathrm{C}_{26} \mathrm{H}_{24} \mathrm{FeO}: \mathrm{M}^{+}$) calcd: 408, 1177; found: 408.1172. Anal. Calcd for $\mathrm{C}_{26} \mathrm{H}_{24} \mathrm{FeO}$ : C, 76.48; H, 5.92. Found: C, 76.39; H, 5.81. 
2-Ferrocenyl-1-(3-hydroxyphenyl)-1-(4-hydroxyphenyl)-but-1-ene, 7. The reaction was performed with $2.14 \mathrm{~g}(10 \mathrm{mmol})$ of the known 3,4'-dihydroxybenzophenone. ${ }^{29}$ The crude product was chromatographed with a solution of $\mathrm{CH}_{2} \mathrm{Cl}_{2}$-acetone $95: 5$ as eluent. The compound was purified on HPLC with acetonitrile-water $70: 30$ as eluent to yield 7 as an orange solid (2.43 g, 58\% yield). The mixture of isomers was recrystallized from ethanol. ${ }^{1} \mathrm{H}$ NMR (300 MHz, $\left.\mathrm{CD}_{3} \mathrm{COCD}_{3}\right) \delta 1.07$ and 1.09 (t, $J=7.4 \mathrm{~Hz}, 3 \mathrm{H}, \mathrm{CH}_{3}$ ), 2.64 and 2.65 (q, $J=$ $7.4 \mathrm{~Hz}, 2 \mathrm{H}, \mathrm{CH}_{2}$ ), 3.96 and 3.97 (t, $\left.J=2.0 \mathrm{~Hz}, 2 \mathrm{H}, \mathrm{C}_{5} \mathrm{H}_{4}\right), 4.10$ and $4.11(\mathrm{t}, J=2.0 \mathrm{~Hz}, 2 \mathrm{H}$, $\mathrm{C}_{5} \mathrm{H}_{4}$ ), 4.15 and 4.16 (s, $5 \mathrm{H}, \mathrm{Cp}$ ), 6.59-6.65 (m, $1 \mathrm{H}, \mathrm{H}_{\text {arom }}$ ), 6.66-7.05 (m, $5 \mathrm{H}, \mathrm{H}_{\text {arom }}$ ), 7.05$7.25\left(\mathrm{~m}, 2 \mathrm{H}, \mathrm{H}_{\text {arom }}\right), 8.12$ and $8.21(\mathrm{~s}, 1 \mathrm{H}, \mathrm{OH}), 8.24$ and $8.27(\mathrm{~s}, 1 \mathrm{H}, \mathrm{OH}) .{ }^{13} \mathrm{C} \mathrm{NMR}$ $\left(\mathrm{CD}_{3} \mathrm{COCD}_{3}\right) \delta 15.9$ and $16.0\left(\mathrm{CH}_{3}\right), 28.2$ and $28.3\left(\mathrm{CH}_{2}\right), 68.8\left(2 \mathrm{CH} \mathrm{C}_{5} \mathrm{H}_{4}\right), 69.9(5 \mathrm{CH} \mathrm{Cp})$, $70.0\left(2 \mathrm{CH} \mathrm{C}_{5} \mathrm{H}_{4}\right), 87.2$ and $87.4\left(\mathrm{C} \mathrm{C}_{5} \mathrm{H}_{4}\right), 113.8$ and $113.9\left(\mathrm{CH}_{\text {arom }}\right), 115.8$ and 115.9 (2 $\left.\mathrm{CH}_{\text {arom }}\right), 116.9$ and $117.3\left(\mathrm{CH}_{\text {arom }}\right), 121.2$ and $121.7\left(\mathrm{CH}_{\text {arom }}\right), 129.9$ and $130.0\left(\mathrm{CH}_{\text {arom }}\right), 131.0$ and $131.5\left(2 \mathrm{CH}_{\text {arom }}\right), 136.8$ and $136.9(\mathrm{C}), 137.2$ and $137.4(\mathrm{C}), 138.7(\mathrm{C}), 147.4$ and 147.6 (C), 156.7 and 156.8 (C), 158.1 and 158.2 (C). IR: 3284, $3397(\mathrm{OH}), 2872,2931,2977,3092$ $\left(\mathrm{CH}_{2}, \mathrm{CH}_{3}\right) \mathrm{cm}^{-1}$. MS (EI, $\left.70 \mathrm{eV}\right) \mathrm{m} / z: 424[\mathrm{M}]^{+\bullet}, 395[\mathrm{M}-\mathrm{Et}]^{+}, 359[\mathrm{M}-\mathrm{Cp}]^{+}, 121[\mathrm{CpFe}]^{+}$. HRMS (EI, $70 \mathrm{eV}, \mathrm{C}_{26} \mathrm{H}_{24} \mathrm{FeO}_{2}: \mathrm{M}^{+}$) calcd: 424.1126, found: 424.1129. Anal. Calcd for $\mathrm{C}_{26} \mathrm{H}_{24} \mathrm{FeO}_{2}$ : C, 73.59; H, 5.70. Found: C, 73.72; H, 5.85.

1,2-di-Ferrocenyl-1-(4-hydroxyphenyl)-but-1-ene, 8. The reaction was performed with $3.06 \mathrm{~g}(10 \mathrm{mmol})$ of the known compound $12 .^{26}$ The crude product was chromatographed with $\mathrm{CH}_{2} \mathrm{Cl}_{2}$ as eluent. The compound was purified on HPLC with acetonitrile-water $90: 10$ as eluent to yield 8 as an orange solid (1.98 g, 39\% yield). The mixture of isomers was recrystallized from an ether-pentane solution. ${ }^{1} \mathrm{H} \mathrm{NMR}\left(300 \mathrm{MHz}, \mathrm{CDCl}_{3}\right) \delta 1.12$ and $1.38(\mathrm{t}$, $\left.J=7.4 \mathrm{~Hz}, 3 \mathrm{H}, \mathrm{CH}_{3}\right), 2.32$ and $2.81\left(\mathrm{q}, J=7.4 \mathrm{~Hz}, 2 \mathrm{H}, \mathrm{CH}_{2}\right), 3.65$ and $3.69(\mathrm{t}, J=1.9 \mathrm{~Hz}, 2$ $\mathrm{H}, \mathrm{C}_{5} \mathrm{H}_{4}$ ), 3.83 and 4.00 (s, $5 \mathrm{H}, \mathrm{Cp}$ ), 4.02 and 4.09 (s, 5H, Cp), 4.00-4.25 (m, $6 \mathrm{H}, \mathrm{C}_{5} \mathrm{H}_{4}$ ), 5.10 and $5.14(\mathrm{~s}, 1 \mathrm{H}, \mathrm{OH}), 6.89$ and $6.90\left(\mathrm{~d}, J=8.5 \mathrm{~Hz}, 2 \mathrm{H}, \mathrm{H}_{\text {arom }}\right), 7.08$ and $7.17(\mathrm{~d}, J=8.5$ $\left.\mathrm{Hz}, 2 \mathrm{H}, \mathrm{H}_{\text {arom }}\right) .{ }^{13} \mathrm{C} \mathrm{NMR}\left(\mathrm{CDCl}_{3}\right) \delta 15.4$ and $15.5\left(\mathrm{CH}_{3}\right), 26.6$ and $30.9\left(\mathrm{CH}_{2}\right), 67.3$ and 68.1 $\left(2 \mathrm{CH} \mathrm{C}_{5} \mathrm{H}_{4}\right), 67.4$ and $68.3\left(2 \mathrm{CH} \mathrm{C}_{5} \mathrm{H}_{4}\right), 68.9$ and $69.0\left(2 \mathrm{CH} \mathrm{C}_{5} \mathrm{H}_{4}\right), 69.1(2 \times 5 \mathrm{CH} \mathrm{Cp})$, 69.6 and $70.1\left(2 \mathrm{CH} \mathrm{C}_{5} \mathrm{H}_{4}\right), 86.8$ and $89.6\left(\mathrm{C} \mathrm{C}_{5} \mathrm{H}_{4}\right), 88.8$ and $89.0\left(\mathrm{C} \mathrm{C}_{5} \mathrm{H}_{4}\right), 114.6$ and 115.2 (2 $\left.\mathrm{CH}_{\text {arom }}\right), 130.2$ and $131.1\left(2 \mathrm{CH}_{\text {arom }}\right), 132.5$ and $134.8(\mathrm{C}), 136.5$ and $136.6(\mathrm{C}), 137.2$ and 137.3 (C), 154.0 and 154.3 (C). IR: $3438(\mathrm{OH}), 3092,2967,2929,2872\left(\mathrm{CH}_{2}, \mathrm{CH}_{3}\right) \mathrm{cm}^{-1}$. MS $(\mathrm{EI}, 70 \mathrm{eV}) \mathrm{m} / z: 516[\mathrm{M}]^{+\bullet}, 451[\mathrm{M}-\mathrm{Cp}]^{+}, 121[\mathrm{CpFe}]^{+}$. HRMS (EI, $70 \mathrm{eV}, \mathrm{C}_{30} \mathrm{H}_{28} \mathrm{Fe}_{2} \mathrm{O}: \mathrm{M}^{+}$) 
calcd: 516.0840, found: 516.0820. Anal. Calcd for $\mathrm{C}_{30} \mathrm{H}_{28} \mathrm{Fe}_{2} \mathrm{O}: \mathrm{C}, 69.79 ; \mathrm{H}, 5.46$. Found: C, 69.91; H, 5.39.

1,2-di-Ferrocenyl-1-(3-hydroxyphenyl)-but-1-ene, 9. The reaction was performed with $3.06 \mathrm{~g}(10 \mathrm{mmol})$ of compound 13. The crude product was chromatographed with $\mathrm{CH}_{2} \mathrm{Cl}_{2}$ as eluent. The compound was purified on HPLC with acetonitrile-water $90: 10$ as eluent to yield 9 as an orange solid (2.00 g, 39\% yield). The mixture of isomers was recrystallized from an ether-pentane solution. ${ }^{1} \mathrm{H} \mathrm{NMR}\left(300 \mathrm{MHz}, \mathrm{CDCl}_{3}\right) \delta 1.14$ and 1.37 (t, $\left.J=7.4 \mathrm{~Hz}, 3 \mathrm{H}, \mathrm{CH}_{3}\right)$, 2.32 and 2.81 (q, $\left.J=7.4 \mathrm{~Hz}, 2 \mathrm{H}, \mathrm{CH}_{2}\right), 3.69$ and $3.74\left(\mathrm{t}, J=1.9 \mathrm{~Hz}, 2 \mathrm{H}, \mathrm{C}_{5} \mathrm{H}_{4}\right), 3.82$ and 4.00 (s, $5 \mathrm{H}, \mathrm{Cp}), 4.04$ and 4.09 (s, $5 \mathrm{H}, \mathrm{Cp}), 4.00-4.25\left(\mathrm{~m}, 6 \mathrm{H}, \mathrm{C}_{5} \mathrm{H}_{4}\right), 4.84$ and 4.87 (s, $1 \mathrm{H}$, $\mathrm{OH}), 6.65-6.95\left(\mathrm{~m}, 3 \mathrm{H}, \mathrm{H}_{\text {arom }}\right), 7.30\left(\mathrm{t}, J=7.9 \mathrm{~Hz}, 1 \mathrm{H}, \mathrm{H}_{\text {arom }}\right){ }^{13} \mathrm{C} \mathrm{NMR}\left(\mathrm{CDCl}_{3}\right) \delta 14.5$ $\left(\mathrm{CH}_{3}\right), 25.5$ and $29.6\left(\mathrm{CH}_{2}\right), 66.4$ and $67.1\left(2 \mathrm{CH} \mathrm{C}_{5} \mathrm{H}_{4}\right), 66.5$ and $67.4\left(2 \mathrm{CH} \mathrm{C}_{5} \mathrm{H}_{4}\right), 67.9$ and $68.0\left(2 \mathrm{CH} \mathrm{C}_{5} \mathrm{H}_{4}\right), 68.2(2 \times 5 \mathrm{CH} \mathrm{Cp}), 68.6$ and $69.0\left(2 \mathrm{CH} \mathrm{C}_{5} \mathrm{H}_{4}\right), 85.6$ and $88.3\left(\mathrm{C} \mathrm{C}_{5} \mathrm{H}_{4}\right)$, 87.4 and $88.5\left(\mathrm{C} \mathrm{C}_{5} \mathrm{H}_{4}\right), 112.0$ and $112.4\left(\mathrm{CH}_{\text {arom }}\right), 114.9$ and $116.0\left(\mathrm{CH}_{\text {arom }}\right), 120.3$ and 121.3 $\left(\mathrm{CH}_{\text {arom }}\right), 127.7$ and $128.2\left(\mathrm{CH}_{\text {arom }}\right), 131.7$ and $133.5(\mathrm{C}), 135.3$ and $135.4(\mathrm{C}), 145.2$ and 145.3 (C), 154.5 and 155.0 (C). IR: 3407 (OH), 3094, 2967, 2975, 2927, $2866\left(\mathrm{CH}_{2}, \mathrm{CH}_{3}\right)$ $\mathrm{cm}^{-1}$. HRMS (CI, $\mathrm{NH}_{3}, \mathrm{C}_{30} \mathrm{H}_{29} \mathrm{Fe}_{2} \mathrm{O}: \mathrm{MH}^{+}$) calcd: 517.0918, found: 517.0922. Anal. Calcd for $\mathrm{C}_{30} \mathrm{H}_{28} \mathrm{Fe}_{2} \mathrm{O}$ : C, 69.79; H, 5.46. Found: C, 69.67; H, 5.48.

\section{Biochemical experiments}

\section{Materials}

Stock solutions $\left(1 \times 10^{-3} \mathrm{M}\right)$ of the ferrocenyl complexes $\mathbf{2}, \mathbf{3}$, and $\mathbf{5 - 9}$ to be tested were prepared in DMSO and were kept at $4{ }^{\circ} \mathrm{C}$ in the dark; under these conditions they are stable at least two months. Serial dilutions in DMSO were prepared just prior to use. A stock solution $\left(1 \times 10^{-3} \mathrm{M}\right)$ of $17 \beta$-estradiol was prepared in ethanol. Dulbecco's modified eagle medium (DMEM) was purchased from Gibco BRL, fetal calf serum from Dutscher, Brumath, France, glutamine, estradiol and protamine sulfate were from Sigma. MCF-7 and MDA-MB-231 cells were from the Human Tumor Cell Bank. Sheep uteri weighing approximately $7 \mathrm{~g}$ were obtained from the slaughterhouse at Mantes-la-Jolie, France. They were immediately frozen and kept in liquid nitrogen prior to use. 


\section{Determination of the Relative Binding Affinity (RBA) of the compounds for ER $\alpha$ and}

ERß. RBA values were measured on ER $\alpha$ from lamb uterine cytosol and on ER $\beta$ purchased in solution from Pan Vera (Madison, WI, USA). Sheep uterine cytosol prepared in buffer A (0.05 M Tris-HCL, $0.25 \mathrm{M}$ sucrose, $0.1 \% \beta$-mercaptoethanol, $\mathrm{pH} 7.4$ at $25 \circ \mathrm{C}$ ) as described previously, ${ }^{14}$ was used as a source of ER $\alpha$. For ER $\beta, 10 \mu 1$ of the solution containing 3500 pmol ml${ }^{-1}$ were added to $16 \mathrm{ml}$ of buffer B (10\% glycerol, $50 \mathrm{mM}$ Bis-Tris-Propane $\mathrm{pH}=9$, $400 \mathrm{mM} \mathrm{KCl}, 2 \mathrm{mM}$ DTT, $1 \mathrm{mM}$ EDTA, 0.1\% BSA) in a silanized flask. Aliquots (200 $\mu \mathrm{l})$ of $\mathrm{ER} \alpha$ in glass tubes or ER $\beta$ in polypropylene tubes were incubated for $3 \mathrm{~h}$ at $0{ }^{\circ} \mathrm{C}$ with [6,7$\left.{ }^{3} \mathrm{H}\right]$-estradiol $\left(2 \times 10^{-9} \mathrm{M}\right.$, specific activity $1.62 \mathrm{TBq}^{-1}$, NEN Life Science, Boston MA) in the presence of nine concentrations of the ferrocenyl complexes $\mathbf{2}, \mathbf{3}$, and $\mathbf{5 - 9}$ to be tested (between $6 \times 10^{-7} \mathrm{M}$ and $6 \times 10^{-9} \mathrm{M}$ for the complexes with RBA values higher than $5 \%$ and between $6 \times 10^{-6} \mathrm{M}$ and $6 \times 10^{-8} \mathrm{M}$ for the compounds with RBA values lower than $5 \%$ ) or of $17 \beta$-estradiol (between $8 \times 10^{-8} \mathrm{M}$ and $7.5 \times 10^{-10} \mathrm{M}$ ). At the end of the incubation period, the fractions of $\left[{ }^{3} \mathrm{H}\right]$-estradiol bound to the estrogen receptors (Y values) were precipitated by addition of a $200 \mu \mathrm{l}$ of a cold solution of protamine sulfate $\left(1 \mathrm{mg} \mathrm{mL}^{-1}\right.$ in water). After a 10 min period of incubation at $4{ }^{\circ} \mathrm{C}$, the precipitates were recovered by filtration on $25 \mathrm{~mm}$ circle glass microfibre filters (GF/C) using a Millipore 12 well filtration ramp. The filters were rinsed twice with cold phosphate buffer and then transferred in $20 \mathrm{ml}$ plastic vials. After addition of $5 \mathrm{ml}$ of scintillation liquid (BCS Amersham) the radioactivity of each fraction was counted in a Packard tri-carb 2100TR liquid scintillation analyzer. The concentration of unlabeled steroid required to displace $50 \%$ of the bound $\left[{ }^{3} \mathrm{H}\right]$-estradiol was calculated for $17 \beta$ estradiol and for each complex by plotting the logit values of $Y$ (logit $Y=\ln (Y / 100-Y)$ versus the mass of the competing complex. The RBA was calculated as follows: RBA of a compound $=$ concentration of estradiol required to displace $50 \%$ of $\left[{ }^{3} \mathrm{H}\right]$-estradiol $\times$ $100 /$ concentration of the compound required to displace $50 \%$ of $\left[{ }^{3} \mathrm{H}\right]$-estradiol. The RBA value of estradiol is by definition equal to $100 \%$.

Measurement of octanol/water partition coefficient $\left(\log \boldsymbol{P}_{\mathrm{o} / \mathrm{w}}\right)$ of the compounds. The $\log P_{\mathrm{o} / \mathrm{w}}$ values of the compounds were determined by reverse-phase HPLC on a C-8 column (Nucleosil 5 C8, from Macherey Nagel, France) according to the method previously described by Minick ${ }^{33}$ and Pomper. ${ }^{34}$ Measurement of the chromatographic capacity factors $(k N)$ for each compounds was performed at various concentrations in the range 85\%-60\% methanol (containing $0.25 \%$ octanol) and an aqueous phase consisting of $0.15 \%$ n-decylamine in 0.02 M MOPS (3-morpholinopropanesulfonic acid) buffer $\mathrm{pH} 7.4$ (prepared in 1-octanol-saturated 
water). These capacity factors $(k N)$ are extrapolated to $100 \%$ of the aqueous component given the value of $k^{\prime} \mathrm{w} \cdot \log P_{\mathrm{o} / \mathrm{w}}(y)$ is then obtained by the formula: $y=0.13418+0.98452 \times \log$ k'w.

\section{Culture conditions}

Cells were maintained in monolayer in DMEM with phenol red supplemented with $8-9 \%$ fetal calf serum and $2 \mathrm{mM}$ glutamine at $37{ }^{\circ} \mathrm{C}$ in a $5 \% \mathrm{CO}_{2}$ air humidified incubator. For proliferation assays, cells were plated in 24-well sterile plates at a density of $1.1 \times 10^{4}$ cells for MDA-MB-231 and of $3 \times 10^{4}$ cells for MCF-7 in $1 \mathrm{~mL}$ of DMEM medium without phenol red, supplemented with $10 \%$ decomplemented and hormone-depleted fetal calf serum and 2 $\mathrm{mM}$ glutamine and incubated. The following day (D0), $1 \mathrm{ml}$ of the same medium containing the compounds to be tested was added to the plates (final volumes of DMSO: $0.1 \%$; 4 wells for each conditions). After 3 days (D3) the incubation medium was removed and fresh medium containing the compounds was added. After 5 days (D5) the total protein content of the plate was analyzed by methylene blue staining as follows. Cell monolayers were fixed for $1 \mathrm{~h}$ in methanol, stained for $1 \mathrm{~h}$ with methylene blue $\left(1 \mathrm{mg} \mathrm{mL}^{-1}\right)$ in PBS, then washed thoroughly with water. One $\mathrm{ml}$ of $\mathrm{HCl}(0.1 \mathrm{M})$ was then added and the absorbance of each well was measured at $620 \mathrm{~nm}$ with a Biorad spectrophotometer. The results are expressed as the percentage of proteins versus the control.

\section{Conclusions}

Our results show that the presence of a $p$-phenol has a significant influence on both the electrochemistry and on the biological efficacy of these ferrocenyl phenol compounds, supporting our hypothesis that oxidative activation to a QM structure may be a key to their biological activity. Compounds $\mathbf{5}$ and $\mathbf{6}$ which do not possess a $p$-phenol also did not show intramolecular electron transfer and rearrangement to a QM structure in the electrochemical experiments, as expected. Compound 5, lacking any kind of phenolic group, showed no appreciable cytotoxicity, while 6, possessing only a $m$-phenol, was much less efficacious than its para-substituted analogue 2. Similarly, compound 7, carrying one $m$ - and one $p$-phenol did not show nearly as strong an activity as that of $\mathbf{3}$, which possesses two $p$-phenols. In fact, the biological activity of 7 is much closer to that of 2 (with $\mathrm{IC}_{50}$ values of 1.13 vs. $1.03 \mu \mathrm{M}$, respectively) than that of $3(0.44 \mu \mathrm{M})$. 
The diferrocenyl compounds $\mathbf{8}$ and $\mathbf{9}$ follow the same trend, with higher biological activity observed for $p$-phenol 8, than $m$-phenol 9. As expected, electron transfer from the phenol to the ferricenium moiety is only electrochemically observed for compound $\mathbf{8}$. However, the activity of these compounds cannot be solely attributed to their electronic and structural rearrangements. There also exists the steric effect of the additional ferrocene group, which has a negative effect on the biological activity of $\mathbf{8}$ and $\mathbf{9}$. Whether carrying a $p$ - or $m$ - phenol, the diferrocenyl compounds are less efficacious than their mono-ferrocenyl analogues $\mathbf{2}$ and $\mathbf{6}$.

Although each of the compounds carrying a $p$-phenol behaves similarly from an electrochemical perspective, the steric effect suggests that the QMs are formed, or react, via one or several specific biological pathways. For example, QMs are alkylating agents which can react with $\mathrm{O}-, \mathrm{N}-$, or $\mathrm{S}$ - nucleophiles, especially glutathione, via a Michael 1,4-addition. ${ }^{35}$ The depletion of glutathione can then lead to the alkylation of proteins by an excess of quinone. Alternatively, quinonoids are known to undergo redox cycling in cells resulting in the production of ROS, via such enzymes as NADPH:cytochrome P450 reductase, NADPH:cytochrome $\mathrm{b}_{5}$ reductase, NADPH:ubiquinone oxidoreductase, and $\mathrm{NAD}(\mathrm{P}) \mathrm{H}$ :quinone oxidoreductase, among others, ${ }^{36}$ and iron-containing compounds are known to produce ROS via the Fenton reaction and $\mathrm{H}_{2} \mathrm{O}_{2}$. We are currently investigating the ROS production of these types of compounds, and we hope that future use of specific ROS probes and enzyme-inhibitors will allow us to begin to unravel the metabolic fate of this new class of cytotoxic ferrocenyl phenolic compounds.

\section{Acknowledgements}

We thank A. Cordaville and M. A. Plamont for technical assistance, and the Agence Nationale de la Recherche for financial support (No. ANR-06-BLAN-0384-01, "FerVect". E. A. H. thanks the NSF (grant no. 0302042) for financial support.

\section{References}

1 V. J. Fiorina, R. J. Dubois and S. Brynes, J. Med. Chem., 1978, 21, 393-395; G. N. Yashchenko, A. A. Shashmurina, G. M. Anoshina, L. A. Gorelova, N. G. Evstigneeva, L. V. Alekseeva and L. B. Radina, Khim.-Farm. Zh., 1978, 12, 68-72; M. Wenzel, M. Schneider and E. Liss, Z. Naturforsch, C: Biosci., 1979, 34, 670-676. 
2 P. Köpf-Maier, H. Köpf and E.W. Neuse, Angew. Chem., Int. Ed. Engl., 1984, 23, 456457; P. Köpf-Meyer, H. Köpf and E.W. Neuse, J. Cancer Res. Clin. Oncol., 1984, 108, 336-340.

3 E. W. Neuse and F. Kanzawa, Appl. Organomet. Chem., 1990, 4, 19-26.

4 J. C. Swarts, E. W. Neuse and G. J. Lamprecht, J. Inorg. Organomet. Polym., 1994, 4, 143-153; E. W. Neuse, Macromol. Symp., 2001, 172, 127-138; J. C. Swarts, D. M. Swarts, D. M. Maree, E. W. Neuse, C. La Madeleine and J. E. Van Lier, Anticancer Res., 2001, 21, 2033-2037; M. T. Johnson, E. Kreft, D. D. N’Da, E. W. Neuse and C. E. J. van Rensburg, J. Inorg. Organomet. Polym., 2003, 13, 255-267; G. Caldwell, M.G. Meirim,E.W. Neuse and C. E. J. van Rensburg, Appl. Organomet. Chem., 1998, 12 , 793-799.

5 C. W. Ong, J. Y. Jeng, S. S. Juang and C. F. Chen, Bioorg. Med. Chem. Lett., 1992, 2, 929-932.

6 V. Scarcia, A. Furlani, B. Longato, B. Corain and G. Pilloni, Inorg. Chim. Acta, 1988, 153, 67-70; D. T. Hill, G. R. Girard, F. L. McCabe, R. K. Johnson, P. D. Stupik, J. H. Zhang, W. M. Reiff and D. S. Eggleston, Inorg. Chem., 1989, 28, 3529-3533; G. Pilloni, R. Graziani, B. Longato and B. Corain, Inorg. Chim. Acta, 1991, 190, 165-167; C. Bincoletto, I. L. S. Terariol, C. R. Oliveira, S. Dreher, D. M. Fausto, M. A. Soufen, F. D. Nascimento and A. C. F. Caires, Bioorg. Med. Chem., 2005, 13, 3047.

7 D.A. Oparin, V. D. Makhaev, V. D. Vilchevskaya, T. I. Zimatkina, Z. V. Motylevich, S. M. Zimatkin, S. V. Zabrodskaya, A. I. Krylova and Y. Y. Gorelikova, Khim.-Farm. Zh., 1996, 30, 11-13.

8 A. Ferle-Vidovic, M. Poljak-Blazi, V. Rapic and D. Skare, Cancer Biother. Radiopharm., 2000, 15, 617-624; C. G. Hartinger, A. A. Nazarov, V. B. Arion, G. Giester, M. Jakupec, M. Galanski and B. K. Keppler, New J. Chem., 2002, 26, 671-673.

9 L. V. Popova, V. N. Babin, Y. A. Belousov, Y. S. Nekrasov, A. E. Snegireva, N. P. Borodina, G. M. Shaposhnikova, O. B. Bychenko, P. M. Raevskii, N. B. Morozova, A. I. Iiyina and K. G. Shitkov, Appl. Organomet. Chem., 1993, 7, 85-94.

10 W. C. M. Duivenvoorden, Y. N. Liu, G. Schatte and H. B. Kraatz, Inorg. Chim. Acta, 2005, 358, 3183-3189; E. W. Neuse, M. G. Meirim and N. F. Blom, Organometallics, $1988,7,2562-2565$.

11 P. N. Kelly, A. Prêtre, S. Devoy, I. O’Rielly, R. Devery, A. Goel, J. F. Gallagher, A. J. Lough and P. T. M. Kenny, J. Organomet. Chem., 2007, 692, 1327-1331; X.Wu, E.R. 
T. Tiekink, I.Kostetski,N.Kocherginsky, A. L. C. Tan, S. B. Khoo, P. Wilairat and M.L. Go, Eur. J. Pharm. Sci., 2006, 27, 175-187.

12 D. Osella, M. Ferrali, P. Zanello, F. Laschi, M. Fontani, C. Nervi and G. Cavigiolio, Inorg. Chim. Acta, 2000, 306, 42-48; G. Tabbi, C. Cassino, G. Cavigiolio, D. Colangelo, A. Ghiglia, I. Viano and D. Osella, J. Med. Chem., 2002, 45, 5786-5796; H. Tamura and M. Miwa, Chem. Lett., 1997, 1177-1178; G. Y. N. Vashisht, D. Jayaraju and A. K. Kondapi, Arch. Biochem. Biophys., 2000, 376, 229-235.

13 A. Vessières, S. Top, P. Pigeon, E. A. Hillard, L. Boubeker, D. Spera and G. Jaouen, J. Med. Chem., 2005, 48, 3937-3940.

14 S. Top, A. Vessières, G. Leclercq, J. Quivy, J. Tang, J. Vaissermann, M. Huché and G. Jaouen, Chem.-Eur. J., 2003, 9, 5223-5236.

15 J. A. Katzenellenbogen and R. Muthyala, Pure Appl. Chem., 2003, 75, 1797-1817; J. A. Dodge, Pure Appl. Chem., 1998, 70, 1725-1733.

16 G. Galati and P. J. O’Brien, Free Radical Biol. Med., 2004, 37, 287-303; M. Kawase, N. Motohashi, J. Molnar and H. Sakagami, in Functional Polyphenols and Carotenes with Antioxidative Action, Research Signpost, Trivandrum, India, 2005, pp. 83-109.

17 A. M. Brzozowski, A. C. Pike, Z. Dauter, R. E. Hubbard, T. Bonn, O. Engstrom, L. Ohman,G. L. Greene, J.-A. Gustafsson and M. Carlquist, Nature, 1997, 389, 753-758; A. C. Pike, A. M. Brzozowski, R. E. Hubbard, T. Bonn, A. G. Thorsell, O. Engstrom, J. Ljunggren, J.-A. Gustafsson and M. Carlquist, EMBO J., 1999, 18, 4608-4618; A. C. W. Pike, A. M. Brzozowski, J. Walton, R. E. Hubbard, A. G. Thorsell, Y. L. Li, J.-A. Gustafsson and M. Carlquist, Structure (Cambridge, MA, US), 2001, 9, 145-153; A. K. Shiau, D. Barstad, P. M. Loria, L. Cheng, P. J. Kushner, D. A. Agard and G. L. Greene, Cell, 1998, 95, 927-937.

18 E. A. Hillard, A. Vessières, L. Thouin, G. Jaouen and C. Amatore, Angew. Chem., Int. Ed., 2006, 45, 285-290.

19 S. Top, A. Vessières, C. Cabestaing, I. Laios, G. Leclercq, C. Provot and G. Jaouen, J. Organomet. Chem., 2001, 637, 500-506.

20 E. A. Hillard, A. Vessières, S. Top, P. Pigeon, K. Kowalski, M. Huché and G. Jaouen, J. Organomet. Chem., 2007, 692, 1315-1326.

21 S. Barlow, H. E. Bunting, C. Ringham, J. C. Green, G. U. Bublitz, S. G. Boxer, J. W. Perry and S. R. Marder, J. Am. Chem. Soc., 1999, 121, 3715-3723; S. Barlow and S. R. Marder, Chem. Commun., 2000, 1555-1562; S. Barlow, Inorg. Chem., 2001, 40, $7047-$ 7053. 
22 S. Fukuzumi, K. Okamoto, Y. Yoshida, H. Imahori, Y. Araki and O. Ito, J. Am. Chem. Soc., 2003, 125, 1007-1013; M. Murata, T. Fujita, M. Yamada, M. Kurihara and H. Nishihara, Chem. Lett., 2000, 29, 1328-1329; M. Murata, M. Yamada, T. Fujita, K. Kojima, M. Kurihara, K. Kubo, Y. Kobayashi and H. Nishihara, J. Am. Chem. Soc., 2001, 123, 12903-12904; M. Kurihara and H. Nishihara, Coord. Chem. Rev., 2002, 226, 125-135.

23 L. Cuffe, R. D. A. Hudson, J. F. Gallagher, S. Jennings, C. J. McAdam, R. B. T. Connelly, A. R. Manning, B. H. Robinson and J. Simpson, Organometallics, 2005, 24, 2051-2060.

24 S. B. Colbran, S. T. Lee, D. G. Lonnon, F. J. D. Maharaj, A. M. McDonagh, K. A. Walker and R. D. Young, Organometallics, 2006, 25, 2216-2224.

25 M. Kurihara, H. Sano, M. Murata and H. Nishihara, Inorg. Chem., 2001, 40, 4-5.

26 A. C. Benyei, C. Glidewell, P. Lightfoot, B. J. L. Royles and D. M. Smith, J. Organomet. Chem., 1997, 539, 177-186.

27 S. Top, B. Dauer, J. Vaissermann and G. Jaouen, J. Organomet. Chem., 1997, 541, 355361.

28 P. Nussbaumer, M. Bilban and A. Billich, Bioorg. Med. Chem. Lett., 2002, 12, $2093-$ 2095.

29 S. Gauthier, J. Y. Sanceau, J. Mailhot, B. Caron and J. Cloutier, Tetrahedron, 2000, 56, 703-709.

30 A.-C. Ribou, J.-P. Launay, M. L. Sachtleben, H. Li and C.W. Spangler, Inorg. Chem., 1996, 35, 3735-3740.

31 M. B. Robin and P. Day, Adv. Inorg. Chem. Radiochem., 1967, 10, 247-423.

32 M. R. Schneider, E. Von Angerer, H. Schönenberger, R. T. Michel and H. P. Fortmeyer, J. Med. Chem., 1982, 25, 1070-1077.

33 D. J. Minick, J. H. Frenz, M. A. Patrick and D. A. Brent, J. Med. Chem., 1988, 31, 1923-1933.

34 M. G. Pomper, H. VanBrocklin, A. M. Thieme, R. D. Thomas, D. O. Kiesewetter, K. E. Carlson, C. J. Mathias, M. J. Welch and J. A. Katzenellenbogen, J. Med. Chem., 1990, 33, 3143-3155.

35 P. W. Fan, F. Zhang and J. L. Bolton, Chem. Res. Toxicol., 2000, 13, 45-52.

36 C. Asche, Mini-Rev.Med. Chem., 2005, 5, 449-467. 